
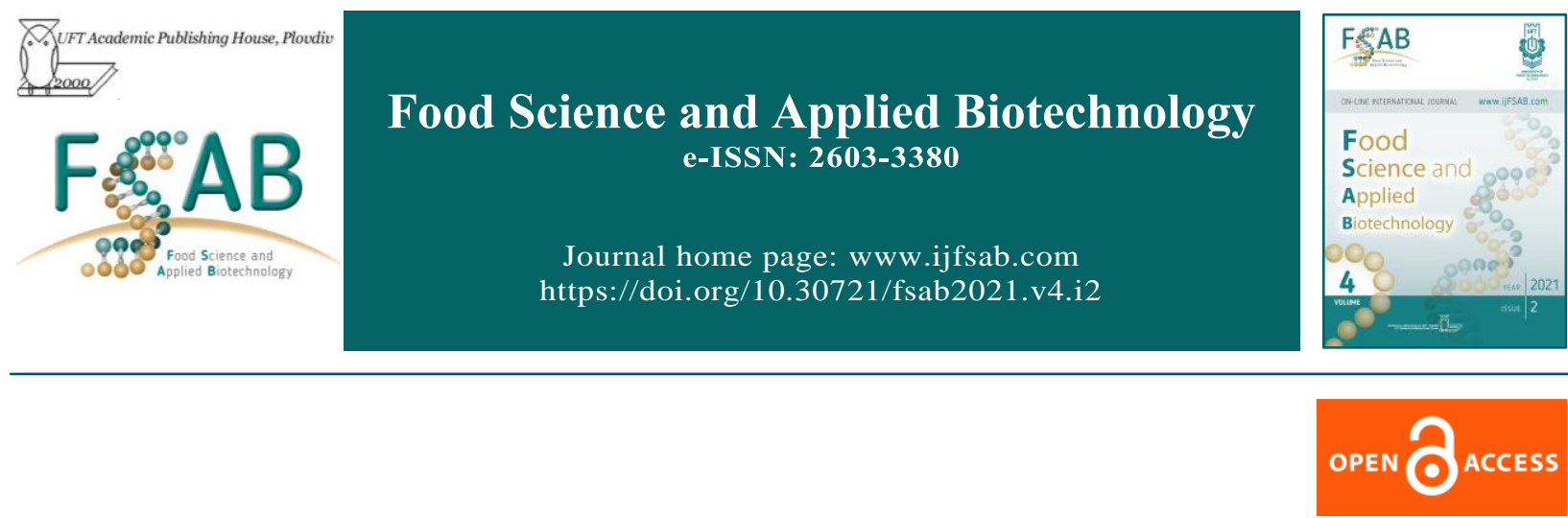

Research Article

\title{
Effects of vacuum frying on the quality of king orange peel in manufacture of chocolate candy fillings
}

\author{
Dinh Thi Hien ${ }^{1 \varpi}$, Hoang Thi Minh Nguyet ${ }^{1}$ \\ ${ }^{I}$ Faculty of Food Science and Technology, Vietnam National University of Agriculture, Hanoi, Vietnam
}

\begin{abstract}
Deep-fried orange peel applied vacuum-frying technique to extend its shelf life and to create crispy product that contains natural nutrients, especially looking for marketplace of the product and increasing the value of orange by-products. The effects of vacuum frying conditions on the quality of fried orange peel was evaluated to produce nutritional chocolate candy fillings that has good sensory values. Orange peel slices were fried under vacuum $(20$ in of $\mathrm{Hg})$ using sunflower frying oil at various temperatures $\left(80^{\circ} \mathrm{C}, 85^{\circ} \mathrm{C}\right.$, $90^{\circ} \mathrm{C}, 95^{\circ} \mathrm{C}$ and $100^{\circ} \mathrm{C}$ ) for different amounts of time $(5,10,15,20,25$ and $30 \mathrm{~min})$. After frying, the fried orange peel slices were centrifuged at $140-1000 \times \mathrm{g}$ for $4 \mathrm{~min}$ to remove the frying oil. Results of this study suggest that vacuum frying at $100^{\circ} \mathrm{C}$ for 30 min showed maximum shrinkage (48\%) and $95 \%$ of carotenoids were lost. The hardness of fried orange peel increased during the frying process. Sensory evaluation showed maximum acceptability for fried orange peels at $90^{\circ} \mathrm{C}$ for $25 \mathrm{~min}$. The TBARS indicated a high deterioration in the atmospheric frying oil quality. In contrast, the vacuum frying condition helped preserve the frying oil quality, while the light color of the product was maintained. The results supported the use of the vacuum frying process as a method for frying high quality king orange peel and conserving the quality of oil in the king orange peel.
\end{abstract}

Keywords: king orange peel; vacuum frying; centrifuge; chocolate candy

Abbreviations: TBARS - 2-Thiobarbituric acid reactive substances, VNUA - Vietnam National University of Agriculture

${ }^{\square}$ Corresponding author: Dinh Thi Hien, Faculty of Food Science and Technology, Vietnam National University of Agriculture, Gia Lam, Hanoi, Vietnam, Mobile: +84369087913, Email: hienhd2001@gmail.com

Article history:

Received 15 July 2020

Reviewed 13 April 2021

Accepted 11 June 2021

Available on-line 10 October 2021

https://doi.org/10.30721/fsab2021.v4.i2.110 (C) 2021 The Authors. UFT Academic publishing house, Plovdiv 


\section{Introduction}

Vacuum frying is an excellent alternative to conventional frying which offers significant benefits such as the improvement of fried product safety and quality and reduced oil oxidation because of the low-temperature processing (Garayo and Moreira 2002). Moreover, the absence of air during vacuum frying may inhibit lipid oxidation and enzymatic browning, and therefore, the color and nutrients of samples can be largely preserved. Deepfat frying of foods usually is carried out under atmospheric conditions at temperatures near 170$2000^{\circ} \mathrm{C}$. The problem that arises most often is excessive darkening or scorching of the product, even before the product is completely cooked. In addition, some of the oil decomposition products have been implicated in producing adverse health effects when fried oils degraded with continued use (Rosana 2014).

Vacuum frying is a deep-fat frying process carried out in a closed system, under atmospheric pressure, substantially reducing the boiling point of water and the frying temperature. The low frying temperatures and minimal exposure to oxygen are responsible for most of the benefits of the fried products, which include nutrient and natural color preservation (Chafer et al. 2001, Fitriyono et al. 2018), oil quality protection (Chafer et al. 2003), and reduction in toxic compound generation (Chafer et al. 2008). At present, vacuum frying technology is widely used for a variety of foods, especially vegetables and fruits. Recent studies showed that this technology has been applied to many subjects such as apples, bananas, jackfruit, kiwi, carrots, mushrooms, sweet potatoes, cassava.

Deep-fried orange peel applied the vacuum-frying technique to extend its shelf life and to create a crispy product that contains natural nutrients, especially looking for the marketplace of the product and increasing the value of orange byproducts. But the question is how to choose the optimal parameters in the frying process to create a product of the best quality possible to meet the increasingly demanding needs of consumers.

The materials are frozen before frying to reduce moisture content and produce low-fat products (Krokida et al. 2001). In addition, maltodextrin may be used for the immersion process which is applied in vacuum frying mango (slice) to significantly improve the structure of the product (Nunes and Moreira 2009). This process can also be combined with citric acid to limit the color change of fried products (Lombard et al. 2008). However, the effects of freezing and frying processes on bioactive compounds in orange peels have not been studied. Therefore, this study is conducted to determine the appropriate parameters for raw material processing, freezing, and vacuum frying for orange peel materials to create fried orange peel products with maximum retention of bioactive components.

\section{Materials and Methods}

\section{Materials}

Fresh king orange at $80-90 \%$ ripeness with yellow skin was purchased from farms at Van Giang, Hung Yen, Viet Nam, they were delivered to the laboratory of Food science and technology - VNUA within $30 \mathrm{~min}$ and stored in cool dry condition. The orange sampling method was implemented according to Vietnam National methods TCVN 5012:1990.

Processing overview of vacuum fried orange peels

Studying the effect of vacuum frying with sunflower oil on changes in the quality of king orange peels:

The orange peel was soaked in sodium bicarbonate $\left(\mathrm{NaHCO}_{3}\right)$ solution at $2 \%(\mathrm{w} / \mathrm{v})$ for $20 \mathrm{~min}$ at a temperature $\left(95^{\circ} \mathrm{C}\right)$ in order to debitter.

The oranges were washed and treated with ozone by an ozone generator (Z775) for $15 \mathrm{~min}$. The oranges were peeled, and peels were cut into $4 \times 0.5 \times$ $0.5 \mathrm{~cm}$. All peel samples were frozen at $-20^{\circ} \mathrm{C}$ for $48 \mathrm{~h}$, and then impregnated with a $45^{\circ}$ Brix sucrose. In this stage of the process, the moisture content of samples was in the range of $60-80 \%$. The sunflower oil used in vacuum frying was imported from Russia. Vacuum frying experiments were conducted at temperatures of $80^{\circ} \mathrm{C}, 85^{\circ} \mathrm{C}, 90^{\circ} \mathrm{C}$, $95^{\circ} \mathrm{C}$, and $100^{\circ} \mathrm{C}$ under vacuum $20^{\prime \prime} \mathrm{Hg}(20$ in of $\mathrm{Hg}$ ) for different amounts of time 5, 10, 15, 20, 25, 30 min (Centricol Ltd, Medellin, Colombia). After frying, the fried orange peels were centrifuged and analyzed product quality attributes include shrinkage, color, hardness, oil absorption, carotenoid content, and sensory analysis 


\section{Methods}

The color of the surface of samples was measured using a colorimeter (Model CR-200 chroma Meter, Minolta, Japan) (Claussen et al. 2007).

Shrinkage was determined by the sample volume measurement method (Prachayawarakorn et al. 2008).

Carotenoids in the fried orange peels were determined by extraction following RodriguezAmaya (2001).

The hardness of the fried orange peels was measured using a Texture Analyzer (TAHdi; Stable Micro Systems, London, UK) (Kotwaliwale et al. 2007). The fried orange peels were evaluated sensory by a method using a nine-point hedonic scale for likeness (Ha Duyen Tu 2010).

Determination of thiobarbituric acid (TBARs) of orange peel as determined in triplicate by a distillation (Tarladgis et al. 1960) and using a spectrophotometer (Thermo Scientific, Genesis 10S UV-Vis, USA) at $538 \mathrm{~nm}$.

The total oil content of coarsely ground orange peel chips was determined by extracting fat with petroleum ether as a solvent by Soxhlet extraction apparatus (AOAC 1997).

\section{Statistical Analysis}

Statistical analysis, calculation, chart was executed using Minitab 18.

\section{Time and place}

The study was conducted from January 2019 to December 2019 in the Faculty of Food Science and Technology

\section{Results and Discussion}

\section{Shrinkage and hardness}

Shrinkage is a common phenomenon during the drying process and it resulted in the change of the hardness during vacuum frying at different times and temperatures. The effect of vacuum frying temperature and time on the shrinkage and the hardness is shown in Fig. 1 and Fig. 2.

Fig. 1 and Fig. 2 show the shrinkage and the hardness of king orange peels during vacuum frying. As soon as the king orange peel slices were introduced in the hot frying medium, the orange slices shrunk. Rapid water loss resulted in significant shrinkage $(p<0.05)$ in king orange peels during the initial $10 \mathrm{~min}$ of vacuum frying. After 15 min of frying at $95^{\circ} \mathrm{C}$ and $100^{\circ} \mathrm{C}$, the change in shrinkage was not significant $(\mathrm{p}<0.05)$ This is due to the fact that at higher temperature sample surface becomes rigid faster due to rapid moisture loss (Nimmol et al. 2007). The shrinkage was increased with the increase of vacuum frying temperature. After 30 min of frying in the temperature range from $80^{\circ} \mathrm{C}-100^{\circ} \mathrm{C}$, the shrinkage in king orange peels fluctuated between $28.5 \%$ and $48.0 \%$, the hardness reduced from $2.85 \mathrm{~N}$ to $2.02 \mathrm{~N}$. High shrinkage and the lowest hardness was shown in fried king orange peel sample at $100^{\circ} \mathrm{C}$ which are due to fast removal of moisture. The results were similar to the other samples. That shows the changes in the shrinkage and the hardness during the vacuum frying process of the king orange peels (Yamsaengsung et al. 2011). Higher shrinkage and lower hardness in potato samples also showed similar results during high-temperature vacuum frying (Yagua and Moreira 2011).

Fig. 1 shows the shrinkage and the hardness of king orange peels during vacuum frying. As soon as the king orange peel slices were introduced in the hot frying medium, the orange slices shrunk. Rapid water loss resulted in significant shrinkage $(\mathrm{P}>$ 0.05 ) in king orange peels during the initial $10 \mathrm{~min}$ of vacuum frying. After $15 \mathrm{~min}$ of frying at $95^{\circ} \mathrm{C}$ and $100^{\circ} \mathrm{C}$, the change in shrinkage was not significant $(P>0.05)$. This is due to the fact that at higher temperature sample surface becomes rigid faster due to rapid moisture loss (Nimmol et al. 2007). The shrinkage was increased with the increase of vacuum frying temperature. 


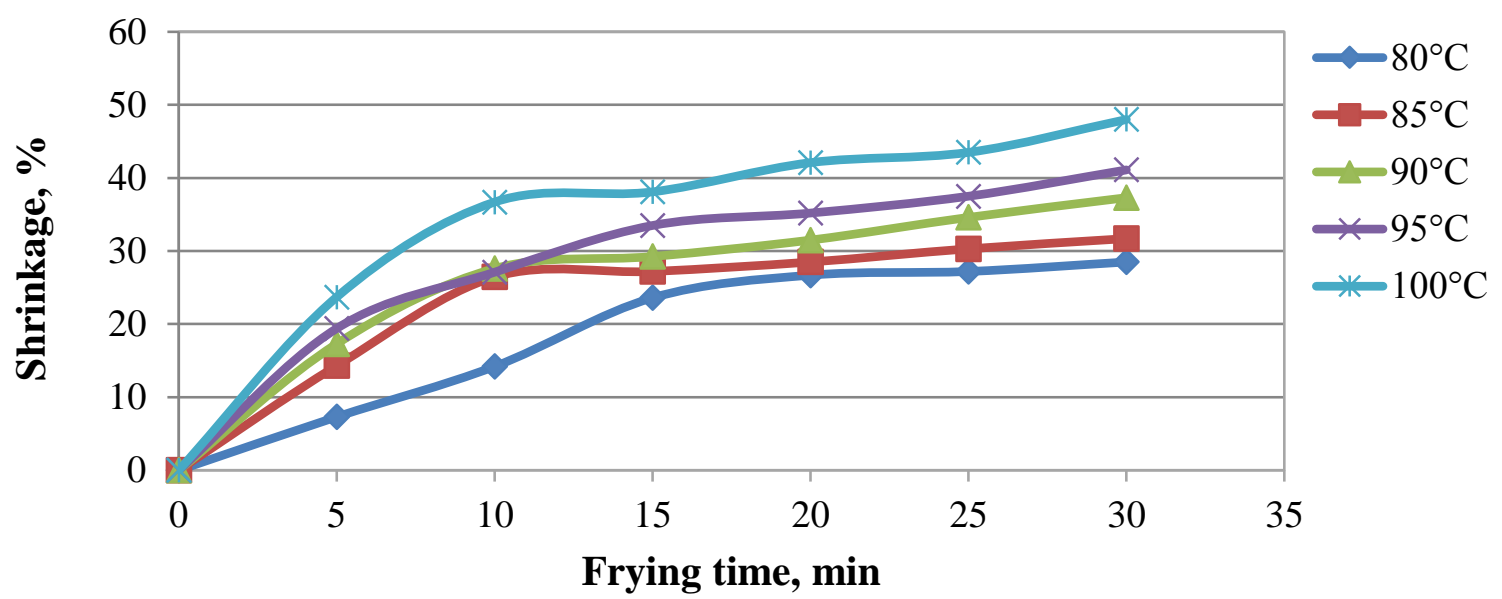

Figure 1. Effect of vacuum frying temperature and time on the shrinkage of king orange peels

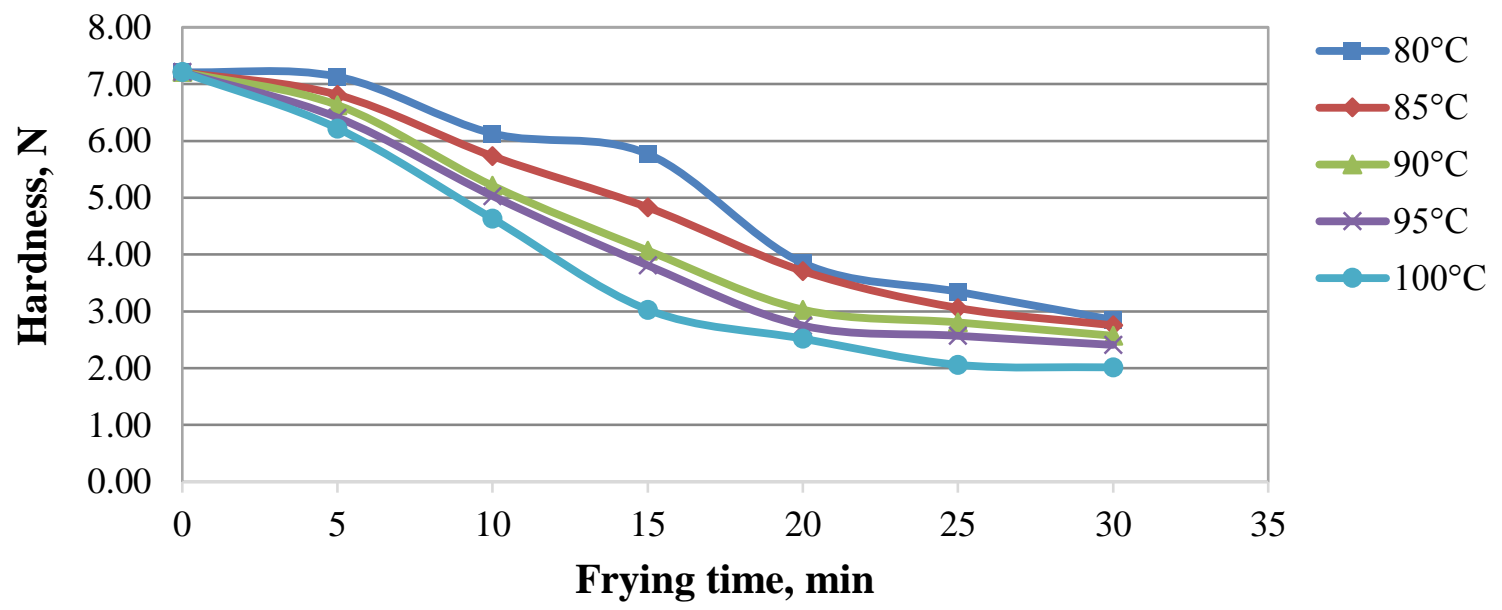

Figure 2. Effect of vacuum frying temperature and time on the hardness of king orange peels

After 30 min of frying in the temperature range from $80^{\circ} \mathrm{C}-100^{\circ} \mathrm{C}$, the shrinkage in king orange peels fluctuated between $28.5 \%$ and $48 \%$, the hardness reduced from $2.85 \mathrm{~N}$ to $2.02 \mathrm{~N}$. High shrinkage and the lowest hardness was shown in fried king orange peel sample at $100^{\circ} \mathrm{C}$ which are due to fast removal of moisture. The results were similar to the other samples. That shows the changes in the shrinkage and the hardness during vacuum frying process of the king orange peels (Yamsaengsung et al. 2011). Higher shrinkage and lower hardness in potato samples also showed similar results during high temperature vacuum frying (Yagua and Moreira 2011).

\section{Oil absorption}

Oil absorption of king orange peel slices at different intervals of time and different vacuum frying temperatures is shown in Fig. 3. Results showed that the oil content of king orange peel slices increased with increasing frying temperatures as well as frying time. Oil absorption was rapid during the initial $15 \mathrm{~min}$ of frying at all the frying temperatures. Almost 1.2-, 1.5-, and 1.8-fold higher 


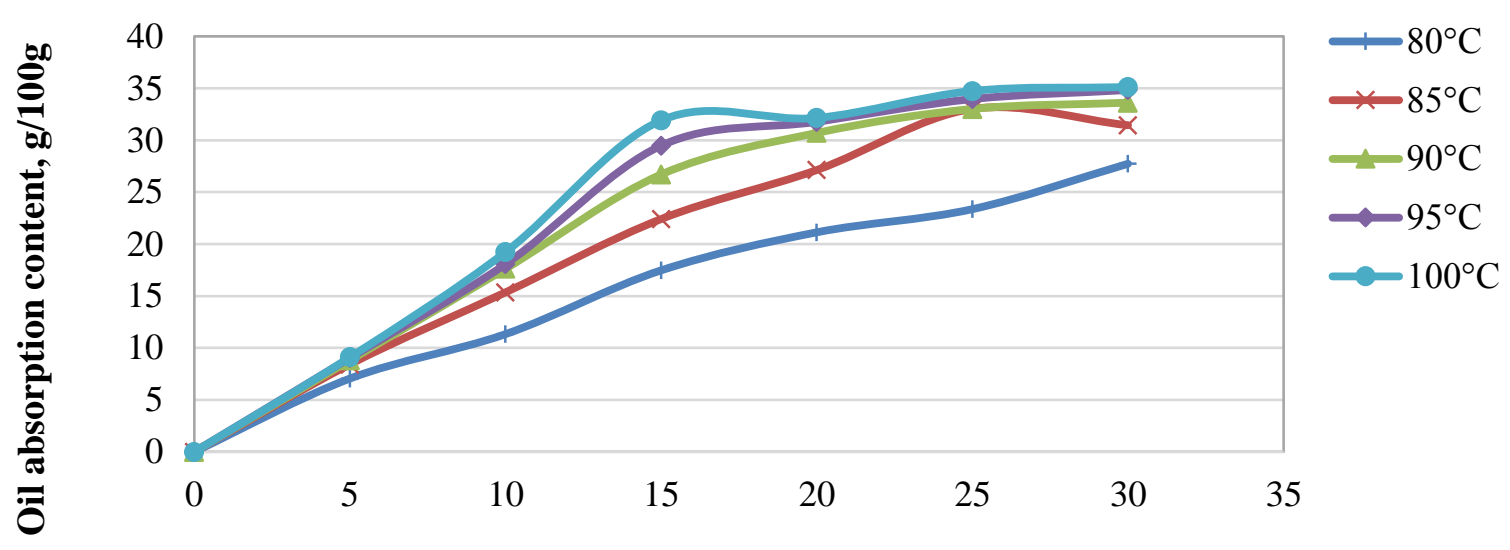

\section{Frying time, min}

Figure 3. Effect of vacuum frying temperature and time on the oil absorption of orange peels

oil absorption when fried under vacuum at $85^{\circ} \mathrm{C}$, $90^{\circ} \mathrm{C}$ and $100^{\circ} \mathrm{C}$ for $15 \mathrm{~min}$, which did not change significantly $(\mathrm{P}<0.05)$ after 15 and 20 min of frying at $90^{\circ} \mathrm{C}$ and $100^{\circ} \mathrm{C}$, respectively. After frying for 30 min, the oil content was found to be $27.3 ; 33.61$, and $35.11 \%$ in king orange peels which were fried at $80^{\circ} \mathrm{C}, 90^{\circ} \mathrm{C}$ and $100^{\circ} \mathrm{C}$, respectively. Studies showed that the oil absorption related to the loss of moisture from the king orange peel slices. This may be due to the diffusion process due to the loss of moisture through the surface making the surface dry (Shyu and Hwang 2001). Our results were similar to a report on Process optimization for the development of vacuum fried papaya (Carica papaya) chips (Pandey and Chauhan 2019).

\section{Color}

The effect of vacuum frying temperature and vacuum frying time on the color parameters of the king orange peels is shown in Fig. 4. The result showed that the $L^{*}$ value of the king orange peels increased during the initial 5 min of frying at all the vacuum frying temperatures. This may be due to the glossiness acquired from the king orange peel slices due to immersion in frying oil. Then, the $\mathrm{L}^{*}$ value decreased with increasing frying time. The change in $\mathrm{L}^{*}$ value was less at a lower temperature. Frying for $25 \mathrm{~min}$ at $90^{\circ} \mathrm{C}$ resulted in only a $13 \%$ reduction in $L *$ value, which continued to reduce to almost $18 \%$ in the next $5 \mathrm{~min}$ of frying. The change in the lightness of king orange peel after frying for $30 \mathrm{~min}$ was almost $13 \%$. Nevertheless, at $100^{\circ} \mathrm{C}$, The $L^{*}$ value reduced to almost $62 \%$ after frying for $30 \mathrm{~min}$ making the color of slices is darker. The decrease in $L^{*}$ value has been related to nonenzymatic browning reactions which accelerate at high temperature (Dueik et al. 2010; Mariscal and Bouchon 2008). The $a^{*}$ value of the vacuum fried king orange peel slices increased significantly with the progress of frying time at all the vacuum frying temperatures. The increase was very rapid at $100^{\circ} \mathrm{C}$ compared to other frying temperatures. Changes in $a^{*}$ value indicated the development of golden brown to dark brown color in orange peel slices due to browning reactions (Brião et al. 2007).

The $b^{*}$ value indicates the yellowness of fried orange peels. Frying under vacuum at all three test temperatures decreased the $b^{*}$ value of orange peel slices to a different level. After frying for $15 \mathrm{~min}$, the king orange peel slices were fried at $100^{\circ} \mathrm{C}$ had $b^{*}$ value that was significantly lower $(\mathrm{P}<0.05)$ than the values corresponding to the king orange peel slices were fried at $80^{\circ} \mathrm{C}$ and $90^{\circ} \mathrm{C}$. After frying for $30 \mathrm{~min}$, the $b^{*}$ value reduced to almost $11 \%, 18 \%$, and $34 \%$ at the frying temperature of $80^{\circ} \mathrm{C}, 90^{\circ} \mathrm{C}$ and $100^{\circ} \mathrm{C}$, respectively. The decrease in $b^{*}$ value may be due to the instability of carotenoids at the higher temperature, according to relevant, the decrease in $b^{*}$ value in vacuum fried carrot chips due to degradation of carotenoids at higher frying temperature (Shyu et al. 2005). 


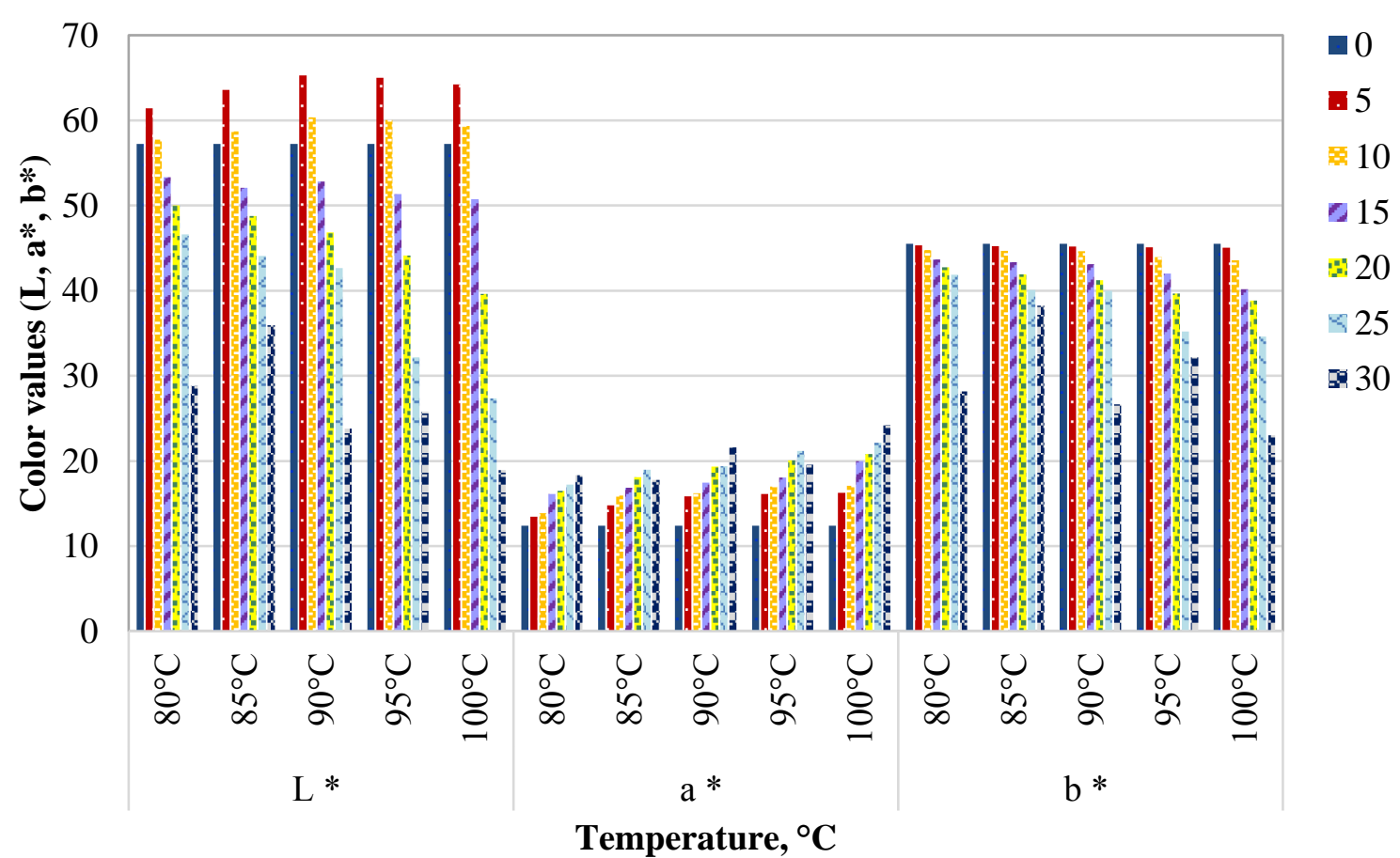

Figure 4. Effect of vacuum frying temperature and time on color parameters of king orange peels

\section{Carotenoid contents}

The yellow color of king orange peel slices is due to the presence of carotenoids.

Change in carotenoid contents during the frying process is shown in Fig. 5.

The carotenoid contents of fresh king orange peel were determined to be $3.31 \mathrm{mg} / 100 \mathrm{~g}$ (dry weight), the result is similar to those of Moreno et al. (2000). After frying for $5 \mathrm{~min} 5,10$, and 14\% of carotenoids were degraded from the initial value in chips fried at $80^{\circ} \mathrm{C}, 90^{\circ} \mathrm{C}$ and $100^{\circ} \mathrm{C}$, respectively. Results also indicated that the rate of degradation of carotenoids was faster after $15 \mathrm{~min}$ of frying at all the frying temperatures. Almost $90 \%$ of carotenoids were degraded when frying at $100^{\circ} \mathrm{C}$ for $30 \mathrm{~min}$. At the end of $30 \mathrm{~min}$ of frying, the total carotenoids were found to be $2.05,1.33$, and $0.41 \mathrm{mg} / 100 \mathrm{~g}$ in king orange peel slices processed at $80^{\circ} \mathrm{C}, 90^{\circ} \mathrm{C}$ and $100^{\circ} \mathrm{C}$, respectively. In an earlier study, almost $95 \%$ of total carotenoids was lost during drying of jack fruit slices at $70^{\circ} \mathrm{C}$ due to oxidation of the pigment, which was accelerated at higher temperature (Saxena et al. 2012).

In our study, the carotenoid contents decreased by $87 \%$ at $100^{\circ} \mathrm{C}$ may be due to the absence of oxygen in the vacuum chamber during frying. The carotenoid molecule has a characteristic conjugated polyene which is very easy to degrade due to oxidation (Boon et al. 2010). Furthermore, carotenoid decreases more or less depending on the heat treatment process, the type of raw material, and the temperature involved in processing (Koca et al. 2007, Ahmed et al. 2002).

\section{Sensory evaluation}

King orange peel slices were evaluated for sensory acceptability in terms of color, crispness, oiliness, flavor, and acceptability, which is shown in Table 1. 


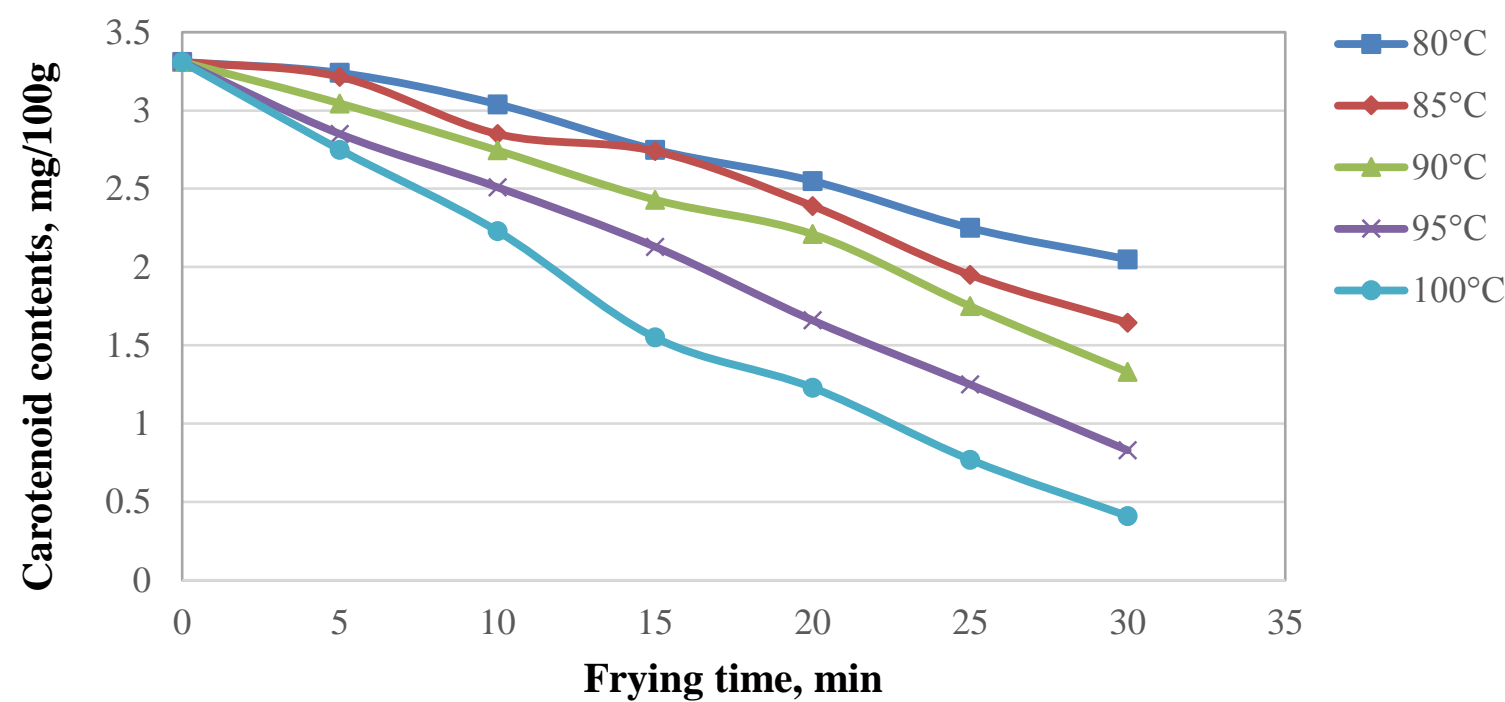

Figure 5. Effect of vacuum frying temperature and time on carotenoid contents of king orange peels

Table 1. Effect of vacuum frying temperature and time on result of sensory evaluation of king orange peels

\begin{tabular}{|c|c|c|c|c|c|c|c|c|c|c|c|c|c|c|c|}
\hline \multirow{2}{*}{$\begin{array}{l}\text { Time, } \\
\text { min }\end{array}$} & \multicolumn{3}{|c|}{ Color } & \multicolumn{3}{|c|}{ Crispness } & \multicolumn{3}{|c|}{ Oiliness } & \multicolumn{3}{|c|}{ Flavor } & \multicolumn{3}{|c|}{$\begin{array}{c}\text { Overall } \\
\text { acceptability }\end{array}$} \\
\hline & $80^{\circ} \mathrm{C}$ & $90^{\circ} \mathrm{C}$ & $100^{\circ} \mathrm{C}$ & $80^{\circ} \mathrm{C}$ & $90^{\circ} \mathrm{C}$ & $100^{\circ} \mathrm{C}$ & $80^{\circ} \mathrm{C}$ & $90^{\circ} \mathrm{C}$ & $100^{\circ} \mathrm{C}$ & $80^{\circ} \mathrm{C}$ & $90^{\circ} \mathrm{C}$ & $100^{\circ} \mathrm{C}$ & $80^{\circ} \mathrm{C}$ & $90^{\circ} \mathrm{C}$ & $100^{\circ} \mathrm{C}$ \\
\hline 0 & $5.00^{\mathrm{a}}$ & $5.00^{\mathrm{a}}$ & $5.00^{\mathrm{a}}$ & $5.22^{\mathrm{a}}$ & $5.30^{\mathrm{a}}$ & $5.23^{\mathrm{a}}$ & $5.50^{\mathrm{a}}$ & $5.50^{\mathrm{a}}$ & $5.50^{\mathrm{a}}$ & $9.00^{\mathrm{a}}$ & $9.00^{\mathrm{a}}$ & $9.00^{\mathrm{a}}$ & $5.00^{\mathrm{a}}$ & $5.00^{\mathrm{a}}$ & $5.00^{\mathrm{a}}$ \\
\hline 5 & $5.27^{\mathrm{a}}$ & $5.28^{\mathrm{a}}$ & $5.51^{\mathrm{a}}$ & $5.24^{\mathrm{a}}$ & $5.80^{\mathrm{a}}$ & $5.50^{\mathrm{a}}$ & $5.45^{\mathrm{a}}$ & $5.61^{\mathrm{a}}$ & $6.58^{b}$ & $8.85^{\mathrm{a}}$ & $8.78^{\mathrm{a}}$ & $8.65^{\mathrm{a}}$ & $5.22^{\mathrm{a}}$ & $5.81^{\mathrm{a}}$ & $5.52^{\mathrm{a}}$ \\
\hline 10 & $5.78^{b}$ & $5.61^{\mathrm{a}}$ & $6.00^{\mathrm{a}}$ & $5.57^{\mathrm{b}}$ & $6.30^{\mathrm{b}}$ & $6.36^{\mathrm{b}}$ & $6.00^{\mathrm{a}}$ & $7.02^{b}$ & $7.35^{\mathrm{c}}$ & $8.67^{\mathrm{a}}$ & $8.16^{\mathrm{a}}$ & $7.88^{b}$ & $5.78^{b}$ & $6.33^{\mathrm{b}}$ & $6.13^{\mathrm{ab}}$ \\
\hline 15 & $6.12^{b}$ & $6.36^{\mathrm{b}}$ & $6.71^{b}$ & $6.00^{\mathrm{b}}$ & $7.11^{\mathrm{b}}$ & $7.85^{\mathrm{c}}$ & $6.57^{b}$ & $7.75^{b}$ & $8.23^{c}$ & $7.95^{\mathrm{b}}$ & $7.86^{\mathrm{b}}$ & $7.05^{\mathrm{b}}$ & $6.12^{b}$ & $7.10^{\mathrm{bc}}$ & $7.85^{\mathrm{b}}$ \\
\hline 20 & $6.58^{b}$ & $6.96^{\mathrm{c}}$ & $7.42^{b}$ & $6.88^{b}$ & $7.82^{b}$ & $8.51^{\mathrm{d}}$ & $7.11^{\mathrm{b}}$ & $7.71^{b}$ & $8.25^{\mathrm{c}}$ & $7.48^{\mathrm{b}}$ & $7.28^{\mathrm{b}}$ & $6.76^{c}$ & $6.88^{b}$ & $7.40^{\mathrm{c}}$ & $8.42^{c}$ \\
\hline 25 & $7.16^{\mathrm{c}}$ & $7.81^{\mathrm{c}}$ & $6.87^{b}$ & $7.25^{\mathrm{c}}$ & $8.51^{\mathrm{c}}$ & $8.60^{\mathrm{d}}$ & $7.00^{\mathrm{b}}$ & $7.43^{b}$ & $8.03^{c}$ & $7.27^{\mathrm{b}}$ & $7.07^{\mathrm{b}}$ & $6.35^{c}$ & $7.25^{\mathrm{c}}$ & $8.50^{\mathrm{d}}$ & $8.05^{\mathrm{c}}$ \\
\hline 30 & $7.66^{c}$ & $7.38^{c}$ & $6.49^{b}$ & $7.75^{\mathrm{c}}$ & $8.60^{c}$ & $8.67^{d}$ & $6.82^{b}$ & $7.35^{b}$ & $8.02^{c}$ & $7.15^{\mathrm{c}}$ & $6.62^{c}$ & $5.76^{\mathrm{d}}$ & $7.60^{c}$ & $8.12^{\mathrm{c}}$ & $7.45^{b}$ \\
\hline
\end{tabular}

${ }^{\mathrm{a}}{ }^{\mathrm{d}}$ Means within a column with different superscript letters are significantly different $(\mathrm{P}<0.05)$. 
Sensory evaluation results have shown that the score for king orange peel slices color was higher during vacuum frying at $80^{\circ} \mathrm{C}$. Frying for longer than $25 \mathrm{~min}$ at $90^{\circ} \mathrm{C}$ and $100^{\circ} \mathrm{C}$ resulted in lowering of sensory color scores due to surface browning as a result of caramelization. At $100^{\circ} \mathrm{C}$, the orange peel slices achieved yellow color in 15 min of frying. The increased frying time resulted in undesirable dark colors in orange peel slices.

Crispness is an important textural attribute that determines the quality of king orange peel slices (Krokida et al. 2001). The crispness in king orange peel slices increased with both temperature and time. The higher temperature of frying achieved crispness faster as compared to lower frying temperatures. Nevertheless, sensory scores for crispness remained unchanged after the achievement of an optimum crispness in the period after $25 \mathrm{~min}$.

The oil absorption of orange peel slices reduced after 15-20 $\mathrm{min}$ of frying which led to a simultaneous increase in sensory scores for oiliness. During initial frying, the slice was found to be very oily. This may be due to incomplete moisture loss and surface oil absorption. The oiliness decreased during the frying process, however, oiliness almost unchanged after $20 \mathrm{~min}$ until the end of $30 \mathrm{~min}$. The flavor of the fresh sample was scored 9 on the hedonic scale. The sensory score decreased during frying at all the frying temperatures. Although the changes in flavor during the initial frying periods were not significant, later changed significantly in king orange peel slices at $100^{\circ} \mathrm{C}$.

This may be due to the degradation of volatile flavor compounds during frying at high temperature. After frying for $30 \mathrm{~min}$ the flavor of king orange peel slices was retained in the king orange peel slices at $80^{\circ} \mathrm{C}$ and $90^{\circ} \mathrm{C}$ which were lost sharply to a score of 5.76 in king orange peel slices at $100^{\circ} \mathrm{C}$. Sensory evaluation results showed that the overall acceptability of king orange peel slices which were fried at $90^{\circ} \mathrm{C}$ for $25 \mathrm{~min}$ was highest with a score of 8.5 .

Effect of frying cycles on moisture and oil content, TBARS and color of orange peel chip

Studied the changes in sunflower oil used in vacuum frying of king orange peel slice, no significand inference $(p<0.05)$ in total polar compound found in 0 - 15 min frying cycles of high oleic sunflower oil. Safety is another topic to be concerned, the oil qualities as free fatty acid, total polar compound and peroxide value using in $35 \mathrm{~min}$ vacuum frying cycles of king orange peel slice should be studied in the further work for the purpose to ensure if the reused frying oil be safe for consumers' health.

Rancidity is often considered an unpleasant flavor in fried foods and can be indicated by the TBARs value. There was no significant difference in TBARs values (0.47-0.53 mg malonaldehyde $\mathrm{kg}^{-1}$ ) of all king orange peel slices during 35 min frying cycles (Table 2).

Table 2. Effect of vacuum frying cycles on TBARs of king orange peel slice

\begin{tabular}{cc}
\hline Frying time, min & TBARS, mg malonaldehyde $\mathbf{~ g g}^{-\mathbf{1}}$ \\
\hline 0 & $0.47 \pm 0.02$ \\
5 & $0.49 \pm 0.02$ \\
10 & $0.50 \pm 0.03$ \\
15 & $0.50 \pm 0.01$ \\
20 & $0.51 \pm 0.03$ \\
25 & $0.53 \pm 0.03$ \\
30 & $0.52 \pm 0.02$ \\
35 & $0.53 \pm 0.03$ \\
\hline
\end{tabular}

According to Crosa et al. (2014), vacuum frying significantly decreased the rate of oil deterioration reactions. This was due to the fact that vacuum frying was operated in a closed system which could retard the oil degradation (Shyu et al. 1998; Crosa et al. 2014).

\section{Conclusion}

Among the deep-fat frying technologies, vacuum frying has significant importance for food manufacturing. The results of this study showed that the oil absorption contents and sensory properties of king orange peel slices such as color, texture, and acceptability increased after frying. Lower frying temperatures will be better retain the carotenoid contents in the product. It can be concluded that king orange peel slices can be achieved optimum quality when they are vacuum fried at $90^{\circ} \mathrm{C}$ for 25 $\mathrm{min}$. The vacuum fried king orange peel slices can be used as oily snacks or in the manufacture of chocolate candy fillings. 


\section{Acknowledgments}

The authors would like to thank the leaders and engineers of Marika Co., Ltd for their collaboration in this study.

\section{References}

AOAC Official Methods of Analysis, Association of Official Analytical Chemists, 16th edition, Arlington, VA, USA, AOAC International, 1997.

Ahmed J., Shivhare U. S., SandhuK. S. Thermal degradation kinetics of carotenoids and visual color of papaya puree. Journal of Food Science, 2002, 67(7): 2692-2695. https://doi.org/10.1111/j.13652621.2002.tb08814.x.

Boon C.S., McClements D.J., Weiss J., Decker E.A., Factors influencing the chemical stability of carotenoids in foods. Critical Reviews in Food Science and Nutrition, 2010, 50(6): 515-532. http://doi.org/10.1080/10408390802565889

VBriã B., Granhen Tavares C.R. Effluent generation by the dairy industry: Preventive attitudes and opportunities. Brazilian Journal of Chemical Engineering, 2007, 24(4): 487-497. https://doi.org/10.1590/S0104-66322007000400003

Chafer M., Gonzalez-Martinez C., Ortola, M.D., Chiralt, A., Fito P. Kinetics of osmotic dehydration in orange and mandarin peels. Journal of Food Process Engineering, 2001, 24, (4): 273-289. https://doi.org/10.1111/j.1745-4530.2001.tb00544.x

Chafer M., González-Martínez C., Chiralt A., Fito P. Microstructure and vacuum impregnation response of citrus peels. Food Research International, 2003, 36(1): 35-41.

http://doi.org/10.1016/S0963-9969(02)00105-9

Chafer M., Perez S., Vargas M., Chiralt A. Stability and quality of minimally processed orange slices. Journal of Food Processing and Preservation, 2008, 32(2): 319-334. https://doi.org/10.1111/j.1745-4549.2008.00181.x

Claussen I.C., Strommen I., Egelandsdal B., Straetkvern K.O. Effects of drying methods on functionality of a native potato protein concentrate. Drying Technology, 2007, 25(6): 1091-1098. http://doi.org/10.1080/07373930701396444

Dueik V., Robert P., Bouchon P. Vacuum frying reduces oil uptake and improves the quality parameters of carrot crisps. Food Chemistry, 2010, 119(3): 11431149.

http://doi.org/10.1016/J.FOODCHEM.2009.08.027

Fitriyono A., Matthijs D., Vincenzo F., RuudV. Effect of vacuum frying on quality attributes of fruits. Food Engineering Reviews, 2018, 10(9): 154-164. https://doi.org/10.1007/s12393-018-9178-x
Garayo J., Moreira R., Vacuum frying of potato chips. Journal of Food Engineering, 2002, 55(2): 181-191. http://doi.org/10.1016/S0260-8774(02)00062-6

Ha Duyen Tu. Food Sensory Analysis. Nha Huat Bank Khoa Hoc Va Hi Thuat, Ha Noi, 2010, 145 pages. Print ISBN: Not specified [in Vietnamese]

Koca N., Burdurlu H.S., Karadeniz F. Kinetics of colour changes in dehydrated carrots. Journal of Food Engineering, 2007, 78(2): 449-455.

http://doi.org/10.1016/j.jfoodeng.2005.10.014

Kotwaliwale N., Bakane P., Verma A. Changes in textural and optical properties of oyster mushroom during hot air drying. Journal of Food Engineering, 2007, 78(4): 1207-1211. https://doi.org/10.1016/j.jfoodeng.2005.12.033

Krokida M., Oreopoulou V., Maroulis Z., MarinosKouris D. Effect of osmotic dedydration pretreatment on quality of french fries. Journal of Food Engineering, 2001, 49(4): 339-345. http://doi.org/10.1016/S0260-8774(00)00232-6

Krokida M.K., Oreopoulou V., Maroulis Z.B., MarinosKouris D. Effect of pretreatment on viscoelastic behaviour of potato strips. Journal of Food Engineering, 2001, 50(1): 11-17. http://doi.org/10.1016/S0260-8774(00)00189-8

Lombard G.E., Oliveira J.C., Fito P., Andrés A. Osmotic dehydration of pineapple as a pretreatment for further drying. Journal of Food Engineering, 2008, 85(2): 277-284.

http://doi.org/10.1016/j.jfoodeng.2007.07.009

Manjarres-Pinzon. K, Cortes-Rodriguez M., RodríguezSandoval E. Effect of drying conditions on the physical properties of impregnated orange peel. Brazilian Journal of Chemical Engineering, 2013, 30(3): 667-676.

https://doi.org/10.1590/S0104-66322013000300023

Mariscal M., Bouchon P. Comparison between atmospheric and vacuum frying of apple slices. Food Chemistry, 2008, 107(4): 1561-1569. https://doi.org/10.1016/j.foodchem.2007.09.031

Moreno Alvarez M.J., Gomez C., Mendoza J., Belen D. Total carotenoids of orange peel (Citrus sinensis L. var. Valencia). Journal of Tecnology and Produccion Agricola, 2000, 17(1): 92-99. https://doi.org/10.1021/jf60060a007

Nimmol C., Devahastin S., Swasdisevi T., Soponronnarit S. Drying of banana slices using combined lowpressure superheated steam and far-infrared radiation. Journal of Food Engineering, 2007, 81(3): 624-633. http://doi.org/10.1016/j.jfoodeng.2006.12.022

Nunes Y., Moreira R.G. Effect of osmotic dehydration and vacuum- frying parameters to produce highquality mango chips. Journal of Food Science, 2009, 
74(7): 355-E362. https://doi.org/10.1111/j.17503841. 2009.01257.x 51

Pandey A.K., Chauhan O.P. Process optimization for development of vacuum fried papaya (Carica papaya) chips using response surface methodology. Agricultural Research, 2019, 8(9): 364-373.

https://doi.org/10.1007/s40003-018-0375-x

Prachayawarakorn S., Tia W., Plyto N., Soponronnarit S. Drying kinetics and quality attributes of low-fat banana slices dried at high temperature. Journal of Food Engineering, 2008, 85(4): 509-517. https://doi.org/10.1016/j.jfoodeng.2007.08.011

Rodriguez-Amaya D.B. A Guide to Carotenoid Analysis in Food. International Life Sciences Institute, One Thomas Circle, N.W. Washington, D.C. 2001, 64 pages. Print ISBN: 1-57881-072-8

Rosana G.M. Vacuum frying versus conventional frying - An overview. European Journal of Lipid Science and Technology, 2014, 116(6): 723-734. https://doi.org/10.1002/ejlt.201300272

Saxena A., Maity T., Raju P.S., Bawa A.S. Degradation kinetics of colour and total carotenoids in jackfruit (Artocarpus heterophyllus) bulb slices during hot air drying. Food and Bioprocess Technology, 2012, 5(2): 672-679. http://doi.org/10.1007/s11947-010-0409-2

Shyu S.L., Hwang L.S. Effects of processing conditions on the quality of vacuum fried apple chips. Food Research International, 2001, 34(2-3): 133-142. http://doi.org/10.1016/S0963-9969(00)00141-1

Shyu S.L., Hau L.-B., Hwang L.S. Effects of processing conditions on the quality of vacuum-fried carrot chips. Journal of the Science of Food and Agriculture, 2005, 85(11): 1903-1908 http://doi.org/10.1002/jsfa.2195

Tarladgis B.G., Watts B.M., Younathan M.T., Dugan L.R.Jr. A distillation method for quantitative determination of malonaldehyde in rancid foods. Journal of American Oil Chemist Society, 1960, 37(1): 44-48. https://doi.org/10.1007/BF02630824

TCVN 5102:1990. ISO 874-1980. Fresh vegetables. Vietnam Standart, Hanoi, Vietnam, 1990 [in Vietnamese]

Yagua C.V., Moreira R.G., Physical and thermal properties of potato chips during vacuum frying. Journal of Food Engineering, 2011, 104(2): 272-283. http://doi.org/10.1016/j.jfoodeng.2010.12.018

Yamsaengsung R., Ariyapuchai T., Prasertsit K. Effects of vacuum frying on structural changes of bananas. Journal of Food Engineering, 2011, 106(4): 298-305.

http://doi.org/10.1016/j.jfoodeng.2011.05.016 